\title{
A Brief Review of the Institutional Impact of Political-Criminal Alliances: In Search of a Suitable Theoretical Framework*
}

\author{
Una breve revisión acerca del impacto institucional de las Alianzas Político-Criminales: en búsqueda de un marco \\ teórico apropiado
}

Diego Alejandro Dominguez M. ${ }^{\text {a }}$

Flinders University, Australia

diego.dominguezmejia@flinders.edu.au

ORCID: http://orcid.org/0000-0001-5088-4121
DOI: https://doi.org/10.11144/Javeriana.papo24-1.brii Redalyc: http://www.redalyc.org/articulo.oa $: \mathrm{id}=77760192005$

Date received: 14 March 2018

Date accepted: 23 July 2018

Date published: 24 June 2019

\begin{abstract}
:
Criminal organizations are capable to make political connections with public servants at different levels (i.e., local, national and transnational). This article provides a review of the literature on the power of the political-criminal alliances to affect the democratic institutions of the State. It also seeks to provide a theoretical framework appropriate to evaluate the impact level that the partnering between criminals and public servants has on the state's scaffolding. The academic work by some experts in criminology has examined the different political impacts that such alliances imply, which includes problems associated with the decay of the criminal judicial system and the creation of impunity umbrellas. However, to date, this research has not provided a theoretical and methodological framework enough to evaluate and measure the true impact of the political-criminal alliances on the state's institutions. Just a few scholars from different fields such as the economics and political science have based their researches on set of theories of systemic corruption and network theories in order to measure the political impact that groups outside the law have on the state. This review stresses the importance of these theoretical concepts in order to evaluate the impact of the politicalcriminal alliances on the institutions, and provides recommendations for future empirical researches and to set out new theories within the same field.
\end{abstract}

Keywords: political-criminal alliances, institutional impact, systemic corruption, illicit networks.

\section{Resumen:}

Las organizaciones criminales son capaces de establecer conexiones ilícitas con oficiales públicos en diferentes niveles (i.e., local, doméstico, y transnacional). Este artículo ofrece una revisión literaria acerca de la capacidad que las alianzas político-criminales poseen para afectar las instituciones democráticas del estado, y busca encontrar un marco teórico apropiado capaz de evaluar el nivel de impacto que la asociación de criminales y oficiales públicos ejerce sobre el aparato público. El trabajo académico de algunos expertos en criminología ha estudiado los diferentes impactos políticos que dichas alianzas conllevan, tales como problemas asociados con el desgaste del sistema judicial criminal y el establecimiento de sombrillas de impunidad. Sin embargo, a la fecha, la investigación no ha ofrecido un marco teórico y metodológico capaz de evaluar y medir el verdadero impacto que las alianzas político-criminales tienen sobre las instituciones del estado. Únicamente, algunos académicos provenientes de diferentes campos tales como la economía y las ciencias políticas han basado su investigación en un conjunto de teorías de corrupción sistémica y teoría de redes, con el fin de medir el impacto político que grupos al margen de la ley ejercen sobre los estados. Esta revisión resalta la importancia de dichos conceptos teóricos, con el fin de evaluar el impacto institucional de las alianzas político-criminales, y ofrece recomendaciones orientadas a futuras investigaciones empíricas y a la formulación de nuevas teorías en el mismo campo.

Palabras clave: alianzas político-criminales, impacto institucional, corrupción sistémica, redes ilícitas.

\section{Author notes:}

${ }^{a}$ Corresponding author. E-mail: diego.dominguezmejia@flinders.edu.au 


\section{Introduction}

Political-criminal alliances have been reported in different places and at various points in time. For example, Kupatadze (2012, p. 29) acknowledges coordinated collaboration between criminals and politicians in various large cities of the United States (US), dating back to the nineteenth century. Kupatadze (2012) also states that political-criminal alliances have existed elsewhere, including China, Colombia, Mexico, and Nigeria.

Criminologists are aware of the continuous manifestation of political-criminal alliances around the world, in which criminals co-opt domestic public officials. However, there has been a lack of attention by criminologists to the political strategies of criminal organizations that account for high levels of criminal violence (Cockayne, 2016, pp. 5-6). Godson (2003a) noted that criminal organizations have the potential to operate and exert political influence across borders. The causes (e.g., criminals being willing to give money to politicians in exchange for protection from law enforcement) and challenges (e.g., the difficulty of conducting official investigations due to bribery of public officials) of domestic and transnational political-criminal alliances are widely acknowledged in the literature (Farah, 2012; Godson, 2003a; Hughes \& Denisova, 2001; Paoli, 1997).

In addition, political-criminal alliances can have negative effects at various levels in society; that is, criminal justice systems can become compromised (Godson, 2003b). What has been studied less is the amount of damage done to the democratic institutions of a country when political-criminal alliances arise. In that regard, there is a lack of conceptual frameworks in the existing collection of mostly descriptive research that are oriented to estimating the institutional effects of political-criminal alliances.

Some scholars in the fields of economics and other social science disciplines have conceptualized the institutional effects of criminal organizations in terms of different forms of political corruption such as corruption and state capture (Hellman \& Kaufmann, 2001; Hellman \& Schankerman, 2000; Hellman, Jones, \& Kaufmann, 2000; World Bank, 1997). In addition, political corruption theorists Garay-Salamanca, Salcedo-Albarán and De León-Beltrán (2009) propose that the extent to which criminal activities affect the democratic institutions of a country depends on the nature of the corruption. For example, payments to officials to obtain the performance of ministerial acts are an example of a corrupt practice. Instances in which politics have been ostensibly manipulated by the power of drug barons can be described as state capture. As such, Garay-Salamanca, Salcedo-Albarán and De León-Beltrán (2010) and Garay-Salamanca and Salcedo-Albarán $(2012,2015)$ have operationalized a set of three theoretical concepts of political corruption: rampant corruption, state capture and co-opted state reconfiguration. This theoretical framework allows scholars to weigh different levels of institutional effects of criminal networks. Additionally, that body of research was able to portray the organizational structure of political-criminal alliances and develop an analytical framework to quantify the specific amount of damage that criminal organizations can inflict on public office.

This article provides a critical review of the extant literature that looks at how the confluence of criminals and public officials has the capacity to impact public institutions (e.g., threatening the security of the rule of law). In order to do that, the article first introduces concepts and definitions that are essential to understand the full effects of political-criminal alliances. Then it proceeds to describe a few well-known cases of political-criminal alliances that have taken place at different places and times. The article then delivers a brief summary of what has been reported by the literature on political-criminal processes and, more specifically, provides a critical review of the literature that looks at how the confluence of criminals and public officials has the capacity to harm the public establishment. The article then describes the limitations encountered, focusing primarily on the lack of theoretical and analytical frameworks to measure the institutional impact of political-criminal alliances. 
The article then introduces a synthesis of three theoretical concepts of systemic political corruption (traditional corruption, state capture and co-opted state reconfiguration). This set of concepts was originally proposed by Garay-Salamanca et al. (2009) as essential for assessing the level of institutional damage exerted by a criminal network. The article then introduces some important theoretical concepts from network theory which can be applied to illicit networks.

Subsequently, the article focuses on the works of Garay-Salamanca et al. (2010), and Garay-Salamanca and Salcedo-Albarán $(2012,2015)$, who have recently started to measure the political influence of politicalcriminal alliances in diverse contexts such as Mexico and Colombia. In closing, the article provides ideas for advancing comparative research and further theory building in the fields of political science, criminology, and security studies.

\section{The Political Scope of Organized Crime}

A "criminal enterprise" or "organized crime" can be defined as a group of individuals that operate outside the law and engage in criminal activities (Finckenauer, 2005). ${ }^{[1]}$ Among criminologists, there has been little consensus on the definition of organized crime. Albanese (2004, p. 9) compiled 11 aspects of organized crime that have been considered in definitions by various authors. Table 1 compiles these characteristics and the number of authors that have included them in their definitions.

TABLE 1.

Definitions of organized crime in the research literature

\begin{tabular}{lc}
\hline Characteristics & Number of authors \\
\hline Organized hierarchy continuing & 16 \\
Rational profit through crime & 17 \\
Use of force or threat & 18 \\
Corruption to maintain immunity & 19 \\
Public demand for services & 20 \\
Monopoly over particular market & 21 \\
Restricted membership & 22 \\
Non-ideological & 23 \\
Specialization & 24 \\
Code of secrecy & 25 \\
Extensive planning & 26 \\
\hline
\end{tabular}


According to Albanese (2004, p. 9), the literature agrees that organized crime functions as a criminal enterprise that seeks to profit through illicit activities. However, there is considerably less consensus about whether organized crime has ideological or political motives for its activities. Finckenauer (2005, p. 81) provides a general definition of organized crime, which he believes satisfies the views of many stakeholders such as legal practitioners, law enforcement officials, scholars, and those who provide legal assistance across national borders:

What is essential to the definition of organized crime is the ability to use, and the reputation for use of violence or the threat of violence to facilitate criminal activities, and in certain instances to gain or maintain monopoly control of particular criminal markets.

On the one hand, specialists in the areas of political science and strategic studies agree that organized crime lacks ideological or political motivations. With that in mind, political scientists have assumed that, as organized crime is not strategic, it does not pursue political power (Cockayne, 2016, p. 15). Kalyvas (2015, p. 1520) argues that "criminal organizations lack both an ideological profile and an explicit political agenda. Furthermore, they do not seek to take over the government-indeed, they don't even pretend to be pursuing this goal." Hence, in general, the concept of organized crime has been structured according to the conventional logic of economic gain and profit (Berdal \& Serrano, 2002, as cited in Cockayne, 2016, p. 15).

Conversely, other scholars are aware of the increasing political scope of organized crime in recent decades. The neoliberal policies of the 1980s and 1990s, such as macro-economic stabilization, deregulation, and privatization, sped up the process of globalization, which brought higher levels of unemployment, scarcer resources, increased income disparity, and increased migration flows (Kaldor, 2012, p. 86). In addition, Kaldor (2012, pp. 1-2) states that, with the advent of globalization and technology, a new era of violence made it difficult to distinguish between war, organized crime, and human rights violations. Scholars from the fields of political science and criminology have acknowledged that, after globalization, "interactions among the disparate criminal groups, insurgents, extremists, and the other non-state actors are poorly understood" (Oehme, 2008, p. 90). This interaction threatens states, challenges the security and stability of democracies, and presents difficulties to authorities, as association between dissimilar groups creates longterm strategies that harness each other's expertise (Dishman, 2005, p. 249). Further, the opportunity to bond fosters a hybridization process that provides illicit groups with new strategic, structural, and operative opportunities, making them difficult for legitimate governments to combat.

This new arrangement of actors performs actions that are difficult to categorize as crimes or political war. Their operations are strategic and coordinated, as they possess the capacity to threaten security. Sullivan (2013, p. 173) calls these new configurations "dark side actors" that, once organized, can produce different hybrid forms. One example is the transnational Central American gangs (maras). Another example is the Albanian mafia, which is linked to ideals, politics, military activities, and terrorism (Makarenko, 2004, p. 136).

In sum, the traditional approach that argues that criminal organizations do not pursue political goals is at odds with mounting evidence of political-criminal collaboration (Cockayne, 2016, p. 16) and with the threat this collaboration poses to the stability of state governance and the global order. A multi-author volume in 2003 (Godson, 2003b) brought attention to the political-criminal nexus (PCN), a local and interstate phenomenon that presents an increasing threat to the rule of law in which organized crime is regularly involved. For Godson (2003a, p. 1), the PCN is collaboration between the political establishment and the criminal underworld. He suggests that such a partnership undermines the rule of law, human rights, and economic development. Contrary to traditional theories of organized crime, the PCN involves criminals seeking partnerships with public actors (e.g., law enforcement officials or politicians) to increase illicit opportunities for profit and to reduce the power of law enforcement (Kelly, 1999, p. 86). 
Reasons that PCNs (hereafter, political-criminal alliances) are formed are various. Collaboration among criminals and politicians brings benefits to both parties. When criminals collaborate with politicians, they can gain protection against law enforcement and competing criminals. Criminals can gain access to information from the police, and intelligence and military agencies to help defeat their adversaries (Godson, 2003a, pp. 8-9). Conversely, political elites pursue collaboration primarily to obtain money for personal or political purposes. Criminals can help politicians by laundering money, providing intelligence on political rivals, and helping them win elections by securing votes in particular areas (Godson, 2003a, p. 9).

\section{Infamous Political-Criminal Alliances}

Political-criminal alliances have emerged in diverse regions of the world. In 2007, when former Colombian paramilitary commander Salvatore Mancuso provided his voluntary confession, he not only recognized his responsibility as perpetrator and co-perpetrator of hundreds of homicides and massacres in the 1990s in Colombia, but he also accepted that his paramilitary group received essential support from a number of public actors in the Colombian government. Among them were high-ranking military officers, politicians — such as the brother of former Colombian President Álvaro Uribe, Senator Mario Uribe-and the police force. According to Mancuso, all of those who participated in the alliance obtained monetary gains derived from the sale of cocaine (Saviano, 2014, pp. 210-211).

In a different part of the world, Maria Licciardi, also known as La Madrina (the Godmother) or La Piccolina (the Little Girl) rose to power as the head of one of the most powerful clans in Naples, Italy, which was affiliated with the Camorra Mafia. Maria Licciardi was the first woman to become the boss of the Licciardi after her brothers (Pietro and Vincenzo) and husband were arrested (Allum, 2007, p. 15). The leadership of Licciardi helped to transform her organization from a "reservoir of cheap labor" into a transnational criminal enterprise dedicated to the narcotics trade. To accomplish that, the Licciardi clan co-opted, enrolled, and got rid of many people in the Neapolitan political system (Saviano, 2017, p. 85). In Naples, the Camorra Mafia, unlike the Sicilian Mafia, did not need to establish alliances with the public sector. It was the politicians who sought help from the system managed by the Mafia (Saviano, 2017, p. 83). Thus, in the absence of a strong state, the Camorra created a system that distributed benefits (Di Gennaro, 2016, p. 24).

In Mexico, through the use of corruption and intimidation, the Beltrán-Leyva cartel captured Mexico's political, judicial, and police institutions. The Mexican cartel operates as a powerful drug-trafficking cartel that is fed classified information, including information about anti-drug operations, by the authorities (Reveles, 2011). In Mexico, the cartels have exerted significant influence on the public administration. Sometimes, the amount of control over Mexican public institutions has been in proportion to the size of the coalitions between cartels (Astorga, 2009). In 2014, the non-consolidated Beltrán-Carrillo-Zetas alliance threatened to give rise to the most powerful paramilitary apparatus in the drug trafficking arena (Astorga, 2010, p. 355). According to Astorga (2009), these alliances gave the cartels territorial control and the capacity to influence government decisions.

\section{The Governance of Organized Crime}

Scholars, leading observers, and analysts have raised serious concerns about the increasing control that criminal organizations are exerting over the public establishment in several regions of the world. Today, the exercise of power of some criminal organizations is not confined to the domestic level, but encompasses transnational domains. In addition, criminal power is not limited to economics, but exists at the social and political levels. For example, Albarracín (2018) highlights how criminal violence and clientelism are used together to influence electoral outcomes in Brazilian urban peripheries. Arias (2010) warns about the 
capacity of criminal groups in Colombia, Brazil, and Jamaica to govern several spheres of society such as security, civil society, elections, and policymaking. For Duncan (2015), in Colombia and Mexico, state and criminal organizations have simultaneously shared and contended with the imposition of the institutions regulating society.

It is not difficult to observe the convergence of political and criminal activities in weak states suffering high levels of corruption such as in Latin America. Miraglia, Ochoa, and Briscoe (2012, p. 2) argue that "conflictaffected and fragile states are especially vulnerable to the dynamics of TOC [transnational organized crime]" and that the implications for those states are considerable such as eroding the state's capacity to deliver public goods, harming the state's legitimacy, and affecting peace processes. The potential for political-criminal alliances to modify public institutions also poses threats to the stability of strong states. In 2011, President Barack Obama warned the US government and the international community about the imminent capacity of criminal networks to expand their operations at a transnational level and forge alliances with corrupt elements of national governments. According to that statement, political-criminal alliances "exploit these relationships to further their interests to the detriment of the United States" (National Security Council, 2011).

The capacity of criminal actors to acquire power in national and international spheres represents threats to the integrity and sovereignty of the state. Increasingly, criminal organizations can challenge and supplant the authority of governments. State erosion can reach a point in which criminal organizations can undermine a government's ability to govern, as observed in Colombia, Italy, and Russia (Godson \& Williams, 1998, p. 67). In addition, criminalized states represent a serious challenge for politicians and international policy analysts. For Naím (2012, p. 101), mafia states dominated by political-criminal alliances blur the conceptual line between state and non-state actors. From that view, this illicit collusion presents a continuous threat to the international community.

Political scientists and international strategists have traditionally followed the Clausewitzian concept of war, which suggests that, although war has many dimensions beyond the political, its eternal essence is merely political: "If the force is not applied for political purposes, then it is not war. It may be sport, or crime, or banditry of a kind integral to local culture, but it is not war" (Gray, 2006, p. 185). On that basis, those fields have traditionally ruled out the capacity of criminal groups to pursue political power. From that perspective, crime, even if it is organized, is not strategic and pursues its objectives according to the logic of economic gain, not political power (Cockayne, 2016, p. 15).

Conversely, some criminologists have resisted the orthodox position of scholars in world politics. The capacity of criminal groups to achieve political power and control over public office, including governance risks (e.g., the deterioration of the rule of law), is mostly unexplored. However, criminologists recognize that political corruption is part of the strategy of criminal groups to maximize economic and political benefits. Kenney (2009, p. 82) emphasizes the value of political power for illicit enterprises. He believes that traffickers seek to reduce exposure to risk and uncertainty by forming social connections with government officials. Their ability to survive the application of law enforcement depends on the accessibility of political power.

For Kelly (2003, p. 104), the field of criminology is yet to adopt a coherent explanatory theory that makes sense of the extent of the political power of organized crime. However, there is extensive literature that explores the capacity of criminal organizations to influence the politics of states. Case studies have recorded the effect of political-criminal connections in various contexts. Based on primary data, Block (1983) delivers a comprehensive historical study that establishes associations between private violence and political, social, and economic life in New York from 1930 to 1950. Andreas (2013) argues that smuggling has played a pivotal role in the birth, expansion to the west, and economic development of the US. Although smuggling activities have dramatically impacted the government's police powers, Andreas believes that the effects of smuggling into the US have been double-edged; not only subverting but also empowering America, economically and politically. 
There are comparative works and case studies that attempt to understand the role of organized crime in shaping the policies and regulations of states at a regional level. Bayart, Ellis and Hibou (1999) describe how African governments are today run by forces linked to international crime. They claim that, shaped by the pressures of globalization and self-enrichment strategies, political-criminal activities in African states go beyond ordinary corruption. These governments regularly liaise with international criminal organizations that are involved in smuggling, drug trafficking, and money laundering. Enrique Desmond Arias, an expert on security and politics in Latin America and the Caribbean, has closely studied the political order of countries in that region. Arias (2010) describes how paramilitaries operating in Medellín communes have successfully established local ownership through programs such as the city's participatory budget initiative and have gained control of state resources flowing into their neighborhood. Using primary research, Arias (2006) has developed a network analysis model to illustrate how criminals operating in Rio de Janeiro's favelas (or shantytowns) have emerged as political actors able to gain access to state resources and power, which has allowed them to further support their activities. Criminals in Rio de Janeiro have consolidated strong local ties with leaders, politicians, and police to build legitimacy and protection in that zone.

Protective economies (or "protective umbrellas"), such as those described by Arias in Rio de Janeiro, have been studied by criminologists in various fragile states. Reitano and Shaw $(2015$, p. 5) observed how rebel separatist groups in West Africa have access to illicit funds derived from cigarette smuggling, drug trafficking, and kidnapping. From that view, these groups have acquired a great capacity to purchase arms, consolidate their monopoly on violence, corrupt state officials, and capture state functions. Criminal organizations in Mali have built legitimacy with local populations and have become the dominant source of subsistence, security and, occasionally, the provision of public services. Similarly, Briscoe and Kalkman (2016, p. 3) account for different cases, such as the Ukraine and Mexico, that have fallen under the influence of criminal organizations that exert control over various state bodies, politicians, judges, police forces, and territories.

According to Cockayne (2016, p. 17) what remains poorly understood is the dynamics and logic behind political-criminal interaction: the why, how, and under what circumstances this illicit collaboration exists. Mandel (2011) attempts to explain when and how transnational organized criminal activities affect individual and state security. His central argument is the idea that criminal organizations use tactics of either corruption or violence or both, depending on whether these groups seek to accept or disrupt the status quo. Criminologists have ignored and underestimated the ideological links between criminals and political elites. The scholarly work of Schulte-Bockholt (2006) and Wilson and Lindsey (2009) supports the idea that nonstate groups, such as gangs and militias, play an essential intermediation role between "the informal politics of the street" and the world of formal politics to consolidate and legitimize localized territorial monopolies and protection economies. Schulte-Bockholt (2006, p. 26) argues that protection rackets emerge when political elites suffer a crisis of hegemony. Such a crisis can occur when states experience rapid economic change and instability.

\section{Towards a Point of Convergence}

Collier (2000, p. 2) concludes that the factors that account for the difference between failure and success in civil wars are not in the "ideological cause" of rebel groups but in their radically different opportunities to raise revenue. This challenging perspective on the nature of civil wars was studied further by other scholars in the area of strategic studies who believe that rapid economic globalization and market-driven free trade provide combatants with a new opportunity to access and transform natural resources into valuable sources of revenue (Ballentine $\&$ Sherman, 2003, p. 2). With the opportunity to obtain a major source of war revenue that changes the rules of conflict, some scholars have realized that modern wars erode the distinction between political conflict and violent organized crime, "creating space for reflection on whether some criminal groups 
may, actually, be strategic actors" (Cockayne, 2016, p. 18). For example, Duffield (2001), Elkus (2011), Felbab-Brown (2010, 2011, 2012, 2013, 2014), Kaldor (2012), and Sullivan and Elkus (2010) support the idea that hybrid groups (e.g., criminal insurgencies) have relied on activities of organized crime to gain political power.

From that perspective, scholars have recognized the dynamics of this new pattern of criminal infiltration of public office. Multidisciplinary efforts include scholars from political and strategic studies, criminologists and practitioners in military fields such as police, intelligence, anti-crime, and counterterrorism (Farah, 2012; Gilman, Goldhammer, \& Weber, 2013; Miklaucic \& Naím, 2013; Williams, 2012). This scholarship has carefully studied transnational organizations that threaten states. These associations take hybrid forms and include actors participating in a variety of illicit activities such as drug trafficking, corruption, terrorism, and religious extremism. New networked structures have demonstrated the ability to adapt, diversify, and converge and reorganize to remain ahead of efforts to combat them. They have achieved a degree of global reach and collaboration through networks and horizontal diversification. Transnational criminal elements have recently been able to generate state capabilities. Through resource development and reorganization, they now rival the capabilities of many states and surpass the capabilities of others (Stavridis, 2013, p. 8).

A multi-author volume in 2003 revealed examples of PCN in diverse regions of the world (Cockayne, 2016, p. 16). It accounted for the myriad institutional effects that this illicit collaboration exerts on the public office of states. The following section describes in detail the findings of this scholarship.

\section{Political-Criminal Alliances: Institutional Impact}

For Godson (2003a), the PCN is a security threat that affects society at political, economic, and social levels and must not be underestimated. For example, political-criminal alliances can affect the legal and health systems of a region. The infrastructure and governance of the rule of law can be put at risk through modification of institutional processes such as the appointment of executive and public figures, public investment decisions (e.g., procurement processes), tax policies, political coalitions in which criminals take part, and judicial decisions (Godson, 2003a, p. 12). Although political-criminal alliances are universal, the literature addressing the problems associated with the collision of the political world and underworld focuses on the regions that are more severely affected by this illicit conspiracy. Hence, it concentrates on southern Italy, Colombia, Nigeria, Mexico, Russia, Ukraine, Taiwan, Hong Kong, China, Central Asia and some parts of Europe and the US.

The existence of political-criminal alliances can affect a state in several ways. Public officials in positions to advance the interests of criminal organizations can make states weak by limiting opportunities for the development of democratic institutions and free markets (Shelley, 2003). Criminals influence sectors of the local economy, such as the credit market, the labor market, and the construction sector, compromising free competition (Paoli, 2003; Pimentel, 2003). Public officials gain wealth by establishing agreements that favor criminals; for example, awarding public contracts to criminals before public bids are invited. When this happens, institutional democracy is compromised and public efficiency is undermined (Ebbe, 2003; Kelly, 2003).

Once political-criminal alliances have weakened a state, it is easier for criminal groups to penetrate its economy with illicit money (Moran, 2001). The success of drug traffickers in Colombia in obtaining highlevel political support was mainly due to the fact that the narcos were able to launder vast amounts of money in a relatively small Colombian economy (Lee \& Thoumi, 2003, p. 85). A weak state affected by politicalcriminal activities results in increased violence and institutions unable to provide basic functions, such as security and protection, to its citizens (Kupatadze, 2008; Solomon \& Foglesong, 2000). 
Another institutional problem created by political-criminal alliances is the weakness of the rule of law and the deterioration of the criminal justice system (Chin, 2003; Shelley, 2003). Criminal groups can obtain protection from political-economic elites by obtaining protective umbrellas (De Danieli, 2014). Hence, when criminal organizations are free to operate under the protective umbrella of law enforcement, the state experiences high levels of impunity. Laws are easily manipulated and inconsistently enforced, and criminals rarely end up in prison and continue to operate (Kelly, 2003; Kupatadze, 2008; Wang, 2011; Williams \& Godson, 2002). For example, in some regions of Mexico, criminality from drug traffickers was out of the reach of lawful authorities (Pimentel, 2003). As another example, Nigerian society has experienced high levels of impunity given that almost the entire judiciary has been corrupted at state and federal levels (Ebbe, 2003).

The influence of political-criminal alliances not only compromises the efficient function of the law and order of a country but also makes criminals the de facto power in that territory. In those cases, criminals can influence elections, control public offices, manage public resources, and collect taxes (Paoli, 2003). When organized crime develops parallel government structures (Kupatadze, 2008) or a "second government" (Chin \& Godson, 2006), corrupt processes are legitimized. A criminalized state and economy uses its power and influence to shape laws in favor of illicit industries (e.g., prostitution and human and drug trafficking) that are under the control of criminal organizations (Hughes \& Denisova, 2001; Jamieson, 2001).

Some countries, such as Mexico and Colombia, have gone through periods of government impotence due to the influence of narco-wealth on their economic and political systems (Lee \& Thoumi, 2003; Pimentel, 2003). Criminal influence on governments to institutionalize narco-mafias and corruption is not unique to Latin America. Central Asian economies have also established symbiotic relationships with drug-related networks in which powerful political figures have worked at the service of drug traffickers (De Danieli, 2014).

\section{Limitations of the Existing Literature}

In sum, criminology and world politics scholarship has disregarded the political side of organized crime. From a criminology and multidisciplinary perspective, there are important efforts that address the dynamics of political-criminal collaboration through important case studies including comparative analysis, which explains the phenomenon at a regional level (e.g., Latin America and Africa). Although these efforts discover similar patterns of corruption and state capture across different countries that explain how political-criminal alliances take place and affect the stability of states, the literature is descriptive and lacks a systematic framework to explain the logic underlying political-criminal interactions. According to Cockayne (2016, p. 19), although some efforts in the literature (e.g., Farah, 2012; Miklaucic \& Naím, 2013) come close to offering a broad framework for understanding the dynamics of political-criminal interactions, such a framework lacks sufficient research to answer questions such as: When do political and criminal actors collaborate? When do they compete? When does one become the other?

In addition, the literature studying the effect of political-criminal alliances on public institutions of states is, for the most part, theoretical. Although several works collect valuable data from ethnographic works, interviews, and field observations (Chin \& Godson, 2006; De Danieli, 2014; Ebbe, 2003; Hughes \& Denisova, 2001; Kupatadze, 2008; Lee \& Thoumi, 2003; Pimentel, 2003), in general the literature is merely descriptive. In addition, in the field of criminology, the magnitude of the political effect of politicalcriminal activities has not been systematically tested, as suggested by the literature on institutional impact. Although attempts to measure institutional impact suggests that the institutional effects are dramatic, there is no agreement among scholars on a comprehensive theoretical and methodological framework to measure the institutional impact of political-criminal processes.

Accordingly, the following section of this article introduces: 1) a set of theoretical concepts of systemic political corruption originally proposed by Garay-Salamanca et al. (2009) as essential to assess the 
institutional impact of political-criminal alliances; and 2) theoretical concepts of social networks that laid the foundations of the methodological mechanism proposed by Garay-Salamanca et al. (2010), and GaraySalamanca and Salcedo-Albarán $(2012,2015)$ to measure the institutional impact of political-criminal processes.

\section{Towards a Theoretical Framework for Assessing the Political Impact of Political-Criminal Alliances}

\section{A Set of Theoretical Concepts of Systemic Political Corruption}

\section{Corruption}

The World Bank (1997, pp. 8-9) defines "corruption" as the abuse of public office for private gain. Public abuse exists:

1) when an official in the exercise of their duties accepts, solicits, or extorts a bribe

2) when a private agent offers bribes to evade public processes to obtain profit

3) when circumstances of patronage and nepotism lead to theft of state assets or diversion of state revenues.

Corruption is common in the private and public sectors but can include participation of illicit groups such as criminal bands, paramilitaries, guerrillas, drug dealers, and gangs (World Bank, 1997). Different factors can trigger corruption. Although the explanations are broad, the decision to act corruptly can be interpreted as balancing the expected cost of a corrupt act -including psychological, social, and financial costs-against the expected benefit (Treisman, 2000, p. 402). In that case, different factors, such as the effectiveness of the legal system, religion, political systems, economic development, and labor conditions, can potentially explain corruption.

Corruption is as old as organized human life (Klitgaard, 1988, p. 7). The timeless nature of corruption goes back to the ancient world. There are historical records that describe corrupt activities in ancient China and India and in the Roman and Greek empires (Farrales, 2005, p. 4). Now, it is not uncommon to hear of corruption scandals. In 2015, after several years of intense investigations, the Swiss authorities arrested various Fédération Internationale de Football Association (FIFA) officials attending the 65th FIFA Congress in Zurich. The arrests were made on behalf of US authorities on corruption charges (Gibson \& Gayle, 2015) and were based on the alleged use of bribery, fraud, and money laundering to corrupt the issuing of media and marketing rights for FIFA games in the Americas, estimated at USD150 million (United States Department of Justice, 2015).

\section{State Capture}

State capture exists when public officials in charge of formulating policies and laws are able to reconfigure the "rules of the game" for their own benefit (Hellman \& Kaufmann, 2001, p. 31). With that in mind, state capture is a more sophisticated form of corruption. It can be described as a "specific form of systemic corruption at large scale" (Garay-Salamanca \& Salcedo-Albarán, 2012, p. 179) in which private agents make fraudulent payments to public officials to alter the formation of norms, rules, and regulations stipulated by the state (Hellman et al., 2000, pp. 6-7). The concept of state capture was formulated in the context of private firms' capacity to capture the public administration. High levels of state capture have a tendency to slow the effect of economic reforms and decrease the quality of governance (Hellman \& Schankerman, 2000, p. 553). 
In general, developing economies that have difficulty applying efficient economic reforms, awarding public contracts, and executing public expenditures are an easy target for actors involved in state capture.

\section{Co-opted State Reconfiguration}

For Garay-Salamanca et al. (2009, pp. 3-6) the concept of state capture falls short of explaining essential aspects of protecting the rule of law. For example, state capture only acknowledges the actions of private agents. However, illegal groups, such as criminal organizations, insurgents, terrorist organizations, or gangs, also have the potential to participate in activities that lead to state capture. In addition, unlawful groups may not only be interested in financial gain but also in obtaining judicial and legislative advantages. State capture only considers scenarios in which the corruption of public officials leads to the alteration of norms, rules, and laws. However, state capture may not only occur at the legislative level but also at the judicial and executive levels.

Co-opted state reconfiguration is a more complex concept of political corruption. The concept of state capture stipulates that the capture process begins at the unlawful end (private actors) and finishes at the lawful end (public actors); for example, firms offering bribes to public agents. Co-opted state reconfiguration suggests that the co-optation process can happen in any direction; it is a two-way process or an alignment of interests between the two parties (Garay-Salamanca et al., 2010).

Co-opted state reconfiguration can be defined as "the action of legal and illegal organizations, which through illegitimate practices seek to systematically modify from within the political regime and influence the formation, modification, interpretation, and application of the rules of the game and public policies" (GaraySalamanca et al., 2009, p. 10). In sum, the main difference between state capture and co-opted state reconfiguration is that, in the latter, interests are coordinated and aligned, regulations are not only affected at the legislative level, and unlawful entities can be represented by any unlawful group such as drug traffickers, guerrillas, or paramilitaries. As with state capture, the objective of co-opted state reconfiguration is to modify the mechanisms that sustain the "rules of the game" of the political regime, including the application of public policies. Hence, unlawful organizations could be interested in altering state standards, regulations, activities, and production of norms. If they succeed, they can obtain sustained economic and political benefits including social legitimacy (Garay-Salamanca \& Salcedo-Albarán, 2012; Garay-Salamanca et al., 2010).

\section{Network Analysis and Analytical Tools for Disrupting Illicit Networks}

Globalization, migration movements, ethnic conflicts, new technologies, and transnational financial markets have provided illicit groups with an opportunity to obtain social, economic, and political power, including the possibility of operating beyond borders (Sullivan, 2000; Williams \& Vlassis, 2001). These versatile groups have grown a considerable capacity to resist pressure from law enforcement and government aggression such as military attacks. Scholars have defined these dynamic structures as illicit networks. After the September 11 attacks, researchers turned their attention to the destructive capabilities of networks. For example, the collection edited by Arquilla and Ronfeldt (2001a) Networks and netwars received considerable attention, as it was published before the attacks and provided the basis for further research on illicit networks (Raab \& Milward, 2003, p. 419).

Network theory and its applications in the field of illicit networks have been of interest to scholars in the areas of international studies, terrorism, and security (Brams, Mutlu, \& Ramírez, 2006; Kinsella, 2006; Krebs, 2002; Montgomery, 2005, 2008; Sageman, 2004). In addition, criminologists have considered the significance of using network analysis to provide recommendations for disrupting criminal networks (Bunker \& Sullivan, 1998; Clarke \& Brown, 2003; Coles, 2001; Eck \& Gersh, 2000; Sarnecki, 2001). By definition, a 
network is a collection of nodes interconnected by links. Although some nodes are popular (i.e., connected to many links), others are isolated (Sageman, 2004, p. 137). For Morselli (2009, p. 4), a network is "a finite set of actors and the relation(s) that define them."

Scholars have discovered common features associated with illicit networks. For example, as networks are social entities, their members can base their relationships on trust, mutual interests, and common experiences (Kenney, 2007; Sageman, 2004; Williams, 2001; Williams \& Vlassis, 2001). In addition, networks can embrace nodes at the core of the group while they can also affiliate nodes at the periphery of the structure. Networks can accommodate sub-networks or clusters. Each sub-network has its own core and periphery. Members located at the core have different roles than members located at the periphery. Networks benefit from their organizational structure, as peripheral nodes protect the core of the structure, making it difficult to penetrate. If a peripheral node is immobilized or targeted, it does not compromise the regular operation of the network (Kenney, 2007; Williams, 2001).

Illicit networks do not have a vertical hierarchical structure, but a flat hierarchical structure with less obvious bureaucratic arrangements. These arrangements are decentralized, dispersed, self-organized, and leaderless (Arquilla \& Ronfeldt, 2001b; Gunaratna, 2002; Williams \& Vlassis, 2001; Zanini \& Edwards, 2001). Researchers have discovered that networks possess significant advantages over traditional hierarchical structures. Networks are highly resilient, easily adapt to different contexts, and are able to readily reorganize to face new challenges (Gunaratna, 2002; Sageman, 2004; Stern, 2003; Sullivan, 2001; Williams, 2001). Moreover, networks have been able to transcend the local sphere. They can take advantage of differences in laws and regulations across regions, allowing them to operate transnationally (Arquilla \& Ronfeldt, 2001b; Williams, 2001; Williams \& Vlassis, 2001). As a result, researchers have identified the importance of using network analysis tools as a key technique for understanding illicit networks. According to McGloin (2005), social network analysis (SNA) provides a comparative advantage over other analytical tools. It focuses more closely on the behaviors of individuals as part of a group. When it comes to disrupting a network, law enforcement can decide to attack the network by either targeting the individual or the group. Similarly, law enforcement can decide that it will be more effective to target individuals at the core of the network rather than at the periphery or vice versa.

\section{Implementing the Theoretical Concepts of Systemic Corruption and Networks to Measure the Institutional Impact of Political-Criminal Alliances}

Based on three political corruption concepts - corruption, state capture, and co-opted state reconfiguration (Garay-Salamanca et al., 2009) - Garay-Salamanca et al. (2010, 2012, 2015) studied various illicit networks [2] and empirically determined the extent to which the confluence of criminal and public officials affects the structure and efficient operation of the institutions of various states. These authors argue that processes of political corruption entail interaction among agents that is either lawful or unlawful. Such interaction can be conceived in terms of social relationships or social situations. As a result, processes of political corruption can be constructed and portrayed as social networks. Thus, this scholarship used SNA to identify essential elements of the illicit networks that were studied. For example, the networks were graphically visualized, their shapes and densities determined, and the leaders operating within the networks were identified; specifically, the agents that held greater levels of individual social capital and those that were capable of arbitrating large amounts of information through other agents. Subsequently, they proposed a methodological tool called Social Network Analysis for Institutional Diagnosis (SNAID) to quantitatively measure the institutional effect of political-criminal processes. SNAID qualifies and then quantifies all actors (or nodes) and relationships (or edges) observed in an illicit network. By doing this, it is able to "identify those sectors and levels of public administration that have been affected by the actions of lawful and unlawful 
agents and groups" (Garay-Salamanca \& Salcedo-Albarán, 2012, p. 186). SNAID typifies every network as a process of corruption, state capture or co-opted state reconfiguration.

\section{Furthering the Work on Measuring the Impact of Political-Criminal Alliances}

Currently, the set of political corruption concepts proposed by Garay-Salamanca et al. (2009) is the only theoretical framework available to assess the impact of political-criminal activities on the institutions of the state. Although this work is an innovative approach to measuring the institutional effect of political-criminal alliances, further theoretical and empirical research is essential to enhance the competency of this theoretical model. Eventually, this will benefit the scholarly community that is interested in better understanding the political effects of political-criminal processes. As such, further research should:

1) construct and portray illicit networks comprised of criminal agents actively involved in transnational political-criminal activities

2) apply SNA techniques to analyze networks involved in political-criminal activities at individual and group levels

3) identify actors and relationships in illicit networks and describe the specific behavior of leaders including their ability to connect groups of individuals in different locations

4) typify the criminal networks as a specific political corruption process in terms of rampant corruption, state capture, or co-opted state reconfiguration

5) identify the actors and relationships associated with processes of corruption, state capture, or co-opted state reconfiguration

6) describe the specific behavior of actors that facilitate relationships that lead to political corruption processes

7) evaluate whether leaders of illicit networks are the same actors in a position to exert political influence upon states.

In general, the theoretical model of Garay-Salamanca et al. (2009) has been used to analyze the institutional impact of political-criminal processes at the local and national levels. Although for example, Salcedo-Albarán and Garay-Salamanca (2016) account for the illicit connections of the FARC with public officials in Peru, the scope of this scholarship in measuring the public effect of these alliances at a transnational level is still scarce. This research proposes that the same model can be applied to study the political impact of politicalcriminal alliances at the transnational level.

Garay-Salamanca et al.s (2009) model has been used in conjunction with network theory to identify the key players that exert political influence upon states. Further research will help to describe in detail the specific criminal behavior and qualifications of key individuals who facilitate connections and lead processes that allow these players to successfully complete their criminal-political activities. Such processes can be analyzed, for example, through the application of network analysis tools such as the G-F metric,[3] which is based on the theories of Gould and Fernández (1989).

\section{Conclusions}

For some time now, scholars have acknowledged the existence and significance of political-criminal alliances (Bailey \& Godson, 2001; Chin \& Godson, 2006; Farah, 2012; Hughes \& Denisova, 2001; Williams \& Godson, 2002). This work also notes the tremendous and potentially dangerous consequences of politicalcriminal alliances, including threats to political, financial, and social orderings (Godson, 2003b; Shelley, 1997). Political-criminal alliances can, and most commonly are, domestic where criminal groups collaborate with public officials within the confines of a particular country or territory. Increasingly, however, politicalcriminal alliances can also be transnational when such groups connect across borders with public officials extraterritorially. 
The reasons why such alliances take place are various. Collaboration among criminals and politicians brings benefits to both parties. When criminals collaborate with the political world, it can bring protection against law enforcement, and from competing criminals. They also can gain access to information from the police, and intelligence and military agencies to help defeat their adversaries (Godson, 2003a, pp. 8-9). Political elites collaborate primarily to obtain money for personal or political purposes. Criminals also can provide money laundering opportunities for politicians, as well as other favors such as providing intelligence on political rivals, and contribute to winning elections by securing votes in particular regions (Godson, 2003a, p. 9).

Even though the impact that political-criminal alliances are able to exert upon the public institutions of a country has been widely debated in the criminology literature, no research has paid attention to delivering a solid theoretical framework that can assess the political influence that political-criminal processes can exert over the public establishment. However, theoretical concepts gathered from diverse research fields have been used to categorize the institutional effects exerted by illicit groups according to different types of systemic political corruption. For example, a state capture process may influence the formulation of laws, regulations, or decrees in a particular country (Hellman \& Schankerman, 2000; Hellman et al., 2000; Hellman \& Kaufmann, 2001); while a "simple" corruption process may, among other things, undermine the effectiveness of aid and support provided to developing countries by international organizations such as the World Bank (World Bank, 1997). A mere case of corruption may have less significant effects on the democratic institutions of a country than state capture (e.g., see Garay-Salamanca et al., 2010; Garay-Salamanca \& Salcedo-Albarán, 2012, 2015).

In addition, very little research has sought to map the confluence of criminal organizations and public institutions. Only a handful of studies have been able to outline the role of internal political-criminal alliances in the formation of illicit networks and have principally focused their efforts upon examining the extent of illicit infiltration of public institutions (e.g., Peoples \& Sutton, 2015; Szwarcberg, 2012). This body of research flags the importance of network theory in studies of organized crime, and demonstrates that social relationships between actors contained within illicit networks (e.g., criminal organizations) and lawful networks (e.g., public institutions) are recordable and can assume different structural forms.

Exceptionally, Garay-Salamanca et al. (2010), and Garay-Salamanca and Salcedo-Albarán (2012, 2015) have based their research upon a set of theoretical concepts of systemic political corruption (traditional corruption, state capture, and co-opted state reconfiguration) and network analysis in order to empirically measure and visualize the level of impact of criminal groups upon the democratic institutions of some Latin American countries such as Colombia and Mexico. That work used a methodological variation of SNA called Social Network Analysis for Institutional Diagnosis (SNAID), which involves analyzing the social relationships and the types of agents of a network. They used SNAID to determine the levels of public administration that have been influenced by obscure alliances among lawful and unlawful actors.

Whilst this body of work represents an important first step in understanding the roles of the actors involved and the extent of the political-criminal alliances formed, such network theory applications have not yet measured and studied such alliances at the transnational level and have omitted to thoroughly elaborate upon the specific role of identified key players that exert political influence either locally or transnationally. The little existing empirical research that deals with this illegitimate collaboration has satisfactorily highlighted the existence of such key players (e.g., brokers) in illicit networks and noted the importance of their role in successfully co-opting public officials. However, further work is needed to examine how illicit objectives (reflective of local or extraterritorial political corruption) are accomplished through such actors.

This research flags a need for further study using such tools as SNA as a means of drawing important connections between criminals and state officials. A deeper understanding of the political role of crime in various parts of the world through "more intense micro-level research into the operations of criminal organizations and the impacts that they have on state institutions and social groups" (Arias, 2006, p. 325) can 
offer solutions to the social violence that many regions face. Such an exercise, Garay-Salamanca et al. (2009) argue, is crucial for preventing future political-criminal alliances in any state.

\section{References}

Albanese, J. S. (2004). North American organised crime. Global Crime, 6(1), 8-18.

Albarracín, J. (2018). Criminalized electoral politics in Brazilian urban peripheries. Crime, Law and Social Change, 69(4), 553-575.

Allum, F. (2007). Doing it for themselves or standing in for their men? Women in the Neapolitan Camorra (1950-2003). In G. Fiandaca (Ed.), Women and the Mafia: Female roles in organized crime structures (pp. 9-17). New York, NY: Springer.

Andreas, P. (2013). Smuggler nation: How illicit trade made America. New York, NY: Oxford University Press.

Arias, E. D. (2006). The dynamics of criminal governance: Networks and social order in Rio de Janeiro. Journal of Latin American Studies, 38(2), 293-325.

Arias, E. D. (2010). Understanding criminal networks, political order and politics in Latin America. In A. L. Clunan, \& H. A. Trinkunas (Eds.), Ungoverned spaces: Alternatives to state authority in an era of softened sovereignty (pp. 115-135). Stanford, CA: Stanford University Press.

Arquilla, J., \& Ronfeldt, D. (Eds.). (2001a). Networks and netwars: The future of terror, crime, and militancy. Santa Monica, CA: Rand Corporation.

Arquilla, J., \& Ronfeldt, D. (2001b). The advent of netwar (revisited). In J. Arquilla, \& D. Ronfeldt (Eds.), Networks and netwars: The future of terror, crime and militancy (pp. 1-28). Santa Monica, CA: Rand Corporation.

Astorga, L. (2009, May 18). México, transición democrática, organizaciones de traficantes e inseguridad. Razón Pública. Retrieved from https://www.fes-seguridadregional.org/images/stories/docs/4776-001_g.pdf

Astorga, L. (2010). México: De la seguridad autoritaria a la inseguridad en la transición democrática. In J. G. Tokatlian (Ed.), Drogas y prohibición: Una vieja guerra, un nuevo debate (pp. 345-386). Buenos Aires, Argentina: Libros del Zorzal.

Bailey, J. J., \& Godson, R. (Eds.). (2001). Organized crime and democratic governability: Mexico and the US-Mexican borderlands. Pittsburgh, PA: University of Pittsburgh Press.

Ballentine, K., \& Sherman, J. (2003). Introduction. In K. Ballentine, \& J. Sherman (Eds.), The political economy of armed conflict: Beyond greed and grievance (pp. 1-15). Boulder, CO: Lynne Rienner.

Bayart, J. F., Ellis, S., \& Hibou, B. (1999). The criminalization of the state in Africa. Bloomington, IN: Indiana University Press.

Block, A. A. (1983). East side west side: Organizing crime in New York 1930-1950. Piscataway, NJ: Transaction Publishers.

Borgatti, S. P., Everett, M. G., \& Freeman, L. C. (2002). UCINET for Windows: Software for social network analysis. Harvard, MA: Analytic Technologies.

Brams, S. J., Mutlu, H., \& Ramírez, S. L. (2006). Influence in terrorist networks: From undirected to directed graphs. Studies in Conflict and Terrorism, 29(7), 703-718.

Briscoe, I., \& Kalkman, P. (2016). The new criminal powers: The spread of illicit links to politics across the world and how it can be tackled. The Hague: Netherlands Institute of International Relations, Clingendael. Retrieved from https://www.clingendael.org/sites/default/files/pdfs/The\%20New\%20Criminal\%20Powers\%20January \%202016.pdf

Bunker, R. J., \& Sullivan, J. P. (1998). Cartel evolution: Potentials and consequences. Transnational Organised Crime, $4(2), 55-74$.

Chin, K., \& Godson, R. (2006). Organized crime and the political-criminal nexus in China. Trends in Organized Crime, 9(3), 5-44. 
Chin, K. L. (2003). Black gold politics: Organized crime, business, and politics in Taiwan. In R. Godson (Ed.), Menace to society: Political-criminal collaborations around the world (pp. 257-79). New Brunswick, NJ: Transaction Publishers.

Clarke, R. V., \& Brown, R. (2003). International trafficking in stolen vehicles. Crime and Justice, 30, 197-227.

Cockayne, J. (2016). Hidden power: The strategic logic of organised crime. New York, NY: Oxford University Press.

Coles, N. (2001). It's not what you know. It's who you know that counts. Analysing serious crime groups as social networks. British Journal of Criminology, 41(4), 580-594.

Collier, P. (2000). Economic causes of civil conflict and their implications for policy. Washington, DC: World Bank. Retrieved from https://web.worldbank.org/archive/website01241/WEB/IMAGES/ECONONMI.PDF

De Danieli, F. (2014). Beyond the drug-terror nexus: Drug trafficking and state-crime relations in Central Asia. International Journal of Drug Policy, 25(6), 1235-1240.

Di Gennaro, G. (2016). Racketeering in Campania: How clans have adapted and how the extortion phenomenon is perceived. Global Crime, 17(1), 21-47.

Dishman, C. (2005). The leaderless nexus: When crime and terror converge. Studies in Conflict \& Terrorism, 28(3), 237-252.

Duffield, M. R. (2001). Global governance and the new wars: The merging of development and security. London, England: Zed Books.

Duncan, G. (2015). Más que plata o plomo: El poder político del narcotráfico en Colombia y México. Bogotá, Colombia: Debate.

Ebbe, O. N. (2003). Slicing Nigeria’s national cake. In R. Godson (Ed.), Menace to society: Political-criminal collaborations around the world (pp. 137-174). New Brunswick, NJ: Transaction Publishers.

Eck, J. E., \& Gersh, J. S. (2000). Drug trafficking as a cottage industry. In M. Natarajan, \& M. Hough (Eds.), Illegal drug markets: From research to prevention policy (pp. 241-272). New York, NY: Criminal Justice Press.

Elkus, A. (2011, June 28). Mexican cartels: A strategic approach. Infinity Journal.

Farah, D. (2012). Transnational organized crime, terrorism, and criminalized states in Latin America: An emerging tier-one national security priority. Carlisle, PA: Strategic Studies Institute, US Army War College.

Farrales, M. J. (2005). What is corruption? A history of corruption studies and the great definitions debate (Working Paper). San Diego, CA: University of California. https://www.doi.org/10.2139/ssrn.1739962

Felbab-Brown, V. (2010). Shooting up: Counterinsurgency and the war on drugs. Washington, DC: Brookings Institution Press.

Felbab-Brown, V. (2011). Human security and crime in Latin America: The political capital and political impact of criminal groups and belligerents involved in illicit economies (Working Paper No. 9/2011). Miami, FL: Western Hemisphere Security Analysis Center. Retrieved from https://www.digitalcommons.fiu.edu/whemsac/40/

Felbab-Brown, V. (2012). Fighting the nexus of organised crime and violent conflict while enhancing human security. In V. Felbab-Brown, \& P. Williams (Eds.), Drug trafficking, violence and instability (pp. 1-26). Carlisle, PA: Strategic Studies Institute, US Army War College. Retrieved from https://www.dtic.mil/docs/citations/ADA 560718

Felbab-Brown, V. (2013). Aspiration and ambivalence: Strategies and realities of counterinsurgency and state-building in Afghanistan. Washington, DC: Brookings Institution Press.

Felbab-Brown, V. (2014). Crime, low-intensity conflict and the future of war in the twenty-first century. In I. Trauschweizer, \& S. Miner (Eds.), Failed states and fragile societies: A new world disorder? (pp. 89-118). Athens, $\mathrm{OH}$ : Ohio University Press.

Finckenauer, J. O. (2005). Problems of definition: What is organized crime? Trends in Organized Crime, 8(3), 63-83.

Garay-Salamanca, L. J., \& Salcedo-Albarán, E. (2012). Institutional impact of criminal networks in Colombia and Mexico. Crime, Law and Social Change, 57(2), 177-194.

Garay-Salamanca, L. J., \& Salcedo-Albarán, E. (2015). Drug trafficking, corruption and states: How illicit networks shaped institutions in Colombia, Guatemala and Mexico. Bloomington, IN: iUniverse. 
Garay-Salamanca, L. J., Salcedo-Albarán, E., \& De León-Beltrán, I. (2009). From state capture towards the co-opted state reconfiguration: An analytical synthesis (Working Paper 61). Bogotá, Colombia: Método Foundation. ht tps://www.doi.org/10.2139/ssrn.1410865

Garay-Salamanca, L. J., Salcedo-Albarán, E., \& De León-Beltrán, I. (2010). Illicit networks reconfiguring states. Bogotá, Colombia: Método Foundation.

Gibson, O., \& Gayle, D. (2015, May). Fifa officials arrested on corruption charges as World Cup inquiry launched. The Guardian. Retrieved from https://www.theguardian.com/football/2015/may/27/several-top-fifa-officials -arrested

Gilman, N., Goldhammer, J., \& Weber, S. (2013). Deviant globalization. In J. Brewer, \& M. Miklaucic (Eds.), Convergence: Illicit networks and national security in the age of globalization (pp. 3-14). Washington, DC: National Defense Unity Press.

Godson, R. (2003a). The political-criminal nexus and global security. In R. Godson (Ed.), Menace to society: Politicalcriminal collaborations around the world (pp. 1-26). New Brunswick, NJ: Transaction Publishers.

Godson, R. (Ed.). (2003b). Menace to society: Political-criminal collaboration around the world. New Brunswick, NJ: Transaction Publishers.

Godson, R., \& Williams, P. (1998). Strengthening cooperation against transnational crime. Survival: Global Politics and Strategy, 40(3), 66-88.

Gould, R. V., \& Fernández, R. M. (1989). Structures of mediation: A formal approach to brokerage in transaction networks. Sociological Methodology, 19, 89-126.

Gray, C. S. (2006). Strategy and history: Essays on theory and practice. New York, NY: Routledge.

Gunaratna, R. (2002). Inside Al Qaeda: Global network of terror. New York, NY: Columbia University Press.

Hellman, J. S., Jones, G., \& Kaufmann, D. (2000). Seize the state, seize the day: State capture, corruption and influence in transition (World Bank Policy Research Working Paper No. 2444). Washington, DC: World Bank.

Hellman, J., \& Kaufmann, D. (2001). La captura del Estado en las economías en transición. Finanzas y Desarrollo, $38(3), 31-35$.

Hellman, J., \& Schankerman, M. (2000). Intervention, corruption and capture: The nexus between enterprises and the state. Economics of Transition, 8(3), 545-576.

Hughes, D. M., \& Denisova, T. A. (2001). The transnational political criminal nexus of trafficking in women from Ukraine. Trends in Organized Crime, 6(3-4), 43-67.

Jamieson, A. (2001). Transnational organized crime: A European perspective. Studies in Conflict and Terrorism, 24(5), 377-387.

Kaldor, M. (2012). New and old wars: Organised violence in a global era. Cambridge, MA: Polity Press.

Kalyvas, S. N. (2015). How civil wars help explain organised crime-And how they do not. Journal of Conflict Resolution, 59(8), 1517-1540.

Kelly, R.J. (2003). An American way of crime and corruption. In R. Godson(Ed.), Menace to society: Political-criminal collaborations around the world (pp. 99-136). New Brunswick, NJ: Transaction Publishers.

Kelly, R. J. (1999). The political-criminal nexus in the United States. Trends in Organized Crime, 5(2), 85-122.

Kenney, M. (2007). From Pablo to Osama: Trafficking and terrorist networks, government bureaucracies, and competitive adaptation. University Park, PA: Penn State Press.

Kenney, M. (2009). Turning to the "dark side": Coordination, exchange and learning in criminal networks. In M. Khaler (Ed.), Networked politics: Agency, power and governance (pp. 79-102). New York, NY: Cornell University Press.

Kinsella, D. (2006). The black market in small arms: Examining a social network. Contemporary Security Policy, 27(1), 100-117.

Klitgaard, R. (1988). Controlling corruption. Berkeley, CA: University of California Press.

Krebs, V. E. (2002). Mapping networks of terrorist cells. Connections, 24(3), 43-52. 
Kupatadze, A. (2008). Organized crime before and after the Tulip Revolution: The changing dynamics of upperworldunderworld networks. Central Asian Survey, 27(3-4), 279-299.

Kupatadze, A. (2012). Organized crime, political transitions and state formation in post-Soviet Eurasia. New York, NY: Springer.

Lee, R. W., \& Thoumi, F. E. (2003). Drugs and democracy in Colombia. In R. Godson (Ed.), Menace to society: Political-criminal collaborations around the world (pp. 71-97). New Brunswick, NJ: Transaction Publishers.

Makarenko, T. (2004). The crime-terror continuum: Tracing the interplay between transnational organised crime and terrorism. Global Crime, 6(1), 129-145.

Mandel, R. (2011). Dark logic: Transnational criminal tactics and global security. Stanford, CA: Stanford University Press.

McGloin, J. (2005). Policy and intervention considerations of a network analysis of street gangs. Criminology \& Public Policy, 4(3), 607-635.

Miklaucic, M., \& Naím, M. (2013). The criminal state. In J. Brewer, \& M. Miklaucic (Eds.), Convergence: Illicit networks and national security in the age of globalization (pp. 149-170). Washington, DC: National Defense Unity Press.

Miraglia, P., Ochoa, R., \& Briscoe, I. (2012). Transnational organised crime and fragile states. (OECD Development Co-operation Working Paper No. 5). Paris, France: OECD. Retrieved from https://www.oecd-ilibrary.org/dev elopment/transnational-organised-crime-and-fragile-states_5k49dfg88s40-en

Montgomery, A. H. (2005). Ringing in proliferation: How to dismantle an atomic bomb network. MIT Press Journals, 30(2), 153-187.

Montgomery, A. H. (2008). Proliferation networks in theory and practice. In J. A. Russell, \& J. J. Wirtz (Eds.), Globalization and WMD proliferation: Terrorism, transnational networks and international security (pp. 28-39). New York, NY: Routledge.

Moran, J. (2001). Democratic transitions and forms of corruption. Crime, Law and Social Change, 36(4), 379-393.

Morselli, C. (2009). Inside criminal networks. New York, NY: Springer.

Naím, M. (2012). Mafia states: Organised crime takes office. Foreign Affairs, 91(3), 100-111.

National Security Council. (2011). Strategy to combat transnational organised crime: Addressing converging threats to national security. Washington, DC: National Security Council. Retrieved from https://www.obamawhiteho use.archives.gov/sites/default/files/microsites/2011-strategy-combat-transnational-organized-crime.pdf

Oehme III, C. G. (2008). Terrorists, insurgents, and criminals. Growing nexus? Studies in Conflict \& Terrorism, 31(1), 80-93.

Paoli, L. (1997). The political-criminal nexus in Italy. Trends in Organized Crime, 3(1), 49-56.

Paoli, L. (2003). Broken bonds: Mafia and politics in Sicily. In R. Godson (Ed.), Menace to society: Political-criminal collaborations around the world (pp. 27-70). New Brunswick, NJ: Transaction Publishers.

Peoples, C. D., \& Sutton, J.E. (2015). Congressional bribery as state-corporate crime: A social network analysis. Crime, Law and Social Change, 64(2-3), 103-125.

Pimentel, S. A. (2003). Mexico's legacy of corruption. In R. Godson (Ed.), Menace to society: Political-criminal collaborations around the world (pp. 175-198). New Brunswick, NJ: Transaction Publishers.

Raab, J., \& Milward, H. B. (2003). Dark networks as problems. Journal of Public Administration Research and Theory, 13(4), 413-439.

Reitano, T., \& Shaw, M. (2015). Fixing a fractured state? Breaking the cycles of crime, conflict and corruption in Mali and Sahel. Geneva, Switzerland: Global Initiative against Transnational Organised Crime. Retrieved from http s://www.globalinitiative.net/wp-content/uploads/2015/06/2015.pdf

Reveles, J. (2011). El cártel incómodo: El fin de los Beltrán Leyva y la hegemonía del Chapo Guzmán. Mexico City, Mexico: Grijalbo.

Sageman, M. (2004). Understanding terror networks. Philadelphia, PA: University of Pennsylvania Press. 
Salcedo-Albarán, E., \& Garay-Salamanca, L. J. (2016). La red 'Montesinos-FARC'. En E. Salcedo-Albarán, \& L. J. Garay-Salamanca (Eds.), Macro-Criminalidad: Complejidad y Resilencia de las Redes Criminales (pp. 1364-1533). Bloomington, IN: iUniverse, Amazon Books.

Sarnecki, J. (2001). Delinquent networks: Youth co-offending in Stockholm. London, England: Cambridge University Press.

Saviano, R. (2014). CeroCeroCero: Cómo la cocaína gobierna el mundo. Barcelona, Spain: Anagrama.

Saviano, R. (2017). Gomorrah: Italy's other Mafia. London, England: Pan Books.

Schulte-Bockholt, A. (2006). The politics of organised crime and the organised crime of politics: A study in criminal power. Lanham, MD: Lexington Books.

Shelley, L. I. (1997). The criminal-political nexus: Russian case study. Trends in Organized Crime, 3(1), 12-14.

Shelley, L. I. (2003). Russia and Ukraine: Transition or tragedy? In R. Godson (Ed.), Menace to society: Politicalcriminal collaborations around the world (pp. 206-37). New Brunswick, NJ: Transaction Publishers.

Solomon, P., \& Foglesong, T. S. (2000). The two faces of crime in post-soviet Ukraine. East European Constitutional Review, 9(3), 72-76.

Stavridis, J. (2013). Foreword. In M. Miklaucic, \& J. Brewer (Eds.), Convergence: Illicit networks and national security in the age of globalisation (pp. 7-10). Washington, DC: National Defense University Press.

Stern, J. (2003). The protean enemy. Foreign Affairs, 82(4), 27-40.

Sullivan, J. (2013). How illicit networks impact sovereignty. In M. Miclaucic, \& J. Brewer (Eds.), Convergence: Illicit networks and national security in the age of globalization (pp. 171-187). Washington, DC: National Defense University Press.

Sullivan, J. P. (2000). Urban gangs evolving as criminal netwar actors. Small Wars \& Insurgencies, 11(1), 82-96.

Sullivan, J. P. (2001). Gangs, hooligans, and anarchists-The vanguard of netwar in the streets. In J. Arquilla, \& D. Ronfeldt (Eds.), Networks and netwars: The future of terror, crime, and militancy (pp. 99-126). Santa Monica, CA: Rand Corporation.

Sullivan, J. P., \& Elkus, A. (2010, August 16). Strategy and insurgency: An evolution in thinking? Opendemocracy. Retrieved from https://www.opendemocracy.net/john-p-sullivan-adam-elkus/strategy-and-insurgency-evoluti on-in-thinking

Szwarcberg, M. (2012). Revisiting clientelism: A network analysis of problem-solving networks in Argentina. Social Networks, 34(2), 230-240.

Treisman, D. (2000). The causes of corruption: a cross-national study. Journal of Public Economics, 76(3), 399-457.

United States Department of Justice. (2015, May 27). Nine FIFA officials and five corporate executives indicted for racketeering conspiracy and corruption. Retrieved from https://www.justice.gov/opa/pr/nine-fifa-officials-and -five-corporate-executives-indicted-racketeering-conspiracy-and

Wang, P. (2011). The Chinese mafia: Private protection in a socialist market economy. Global Crime, 12(4), 290-311.

Williams, P. (2001). Transnational criminal networks. In J. Arquilla, \& D. Ronfeldt (Eds.), Networks and netwars: The future of terror, crime, and militancy (pp. 61-97). Santa Monica, CA: Rand Corporation.

Williams, P. (2012). Insurgencies and organised crime. In V. Felbab-Brown, \& P. Williams (Eds.), Drug trafficking, violence and instability (pp. 27-72). Carlisle, PA: Strategic Studies Institute, US Army War College. Retrieved from https://www.apps.dtic.mil/dtic/tr/fulltext/u2/a560718.pdf

Williams, P., \& Godson, R. (2002). Anticipating organized and transnational crime. Crime, Law and Social Change, 37(4), 311-355.

Williams, P., \& Vlassis, D. (Eds.). (2001). Combating transnational crime: Concepts, activities, and responses. London, England: Frank Cass.

Wilson, E., \& Lindsey, T. (Eds.). (2009). Government of the shadows: Parapolitics and criminal sovereignty. London, England: Pluto Press.

World Bank. (1997). Helping countries combat corruption: The role of the World Bank. Washington, DC: World Bank. 
Zanini, M., \& Edwards, S. J. (2001). The networking of terror in the information age. In J. Arquilla, \& D. Ronfeldt (Eds.), Networks and netwars: The future of terror, crime, and militancy (pp. 29-60). Santa Monica, CA: Rand Corporation.

\section{Notes}

[1] For Finckenauer (2005, p. 64), offences committed by criminals acting in groups should not necessarily be regarded as offences of criminal organisations.

[2] The Familia Michoacana in Mexico, the Autodefensas Campesinas del Casanare in Colombia, and the Autodefensas Unidas de Colombia (Garay-Salamanca et al., 2010; Garay-Salamanca \& Salcedo-Albarán, 2012, 2015).

[3] Available in SNA software such as UCINET (Borgatti, Everett, \& Freeman, 2002).

* Research article

\section{Licencia Creative Commons CC BY 4.0}

How to cite this article: Domínguez, D. A. (2019). A brief review of the institutional impact of politicalcriminal alliances: In search of a suitable theoretical framework. Papel Politico, 24(1). https://doi.org/10.1 1144/Javeriana.papo24-1.brii 